\title{
Nainen numeroiden takana
}

Tiina Vainio (toim. 2000) Naisten talouskoulu. GAUDEAMUS

\section{Naiset ja talous ovat} teemoja, joiden yhdistäminen on tärkeää, vaan ei aina helppoa. Toisaalta talous ja naiset ovat kuitenkin yhdistelmänä kiinnostava käsitepari, joka näyttää avaavan reitin monien yhteiskunnassa tällä hetkellä vaikuttavien ilmiöiden tarkasteluun. Näiden käsitteiden heittämän haasteen on ottanut vastaan joukko kokeneita tutkijoita, joilta on ilmestynyt "Naisten talouskirja" -nimellä otsikoitu artikkelikokoelma. Kirja tuo esiin erilaisia näkökulmia naisten ja talouden välisiin suhteisiin kymmenen kirjoittajan voimin.

\section{Nykyisin hyvin monet} yhteiskunnalliset kysymykset näyttävät liittyvän talouteen tai kääntyvät keskusteluksi taloudesta. Talouden nimissä vaaditaan yhtä ja toista nykyisissä yhteiskunnissa. Esimerkiksi suomalaisessa poliittisessa päätöksenteossa näyttää yleistyneen keskustelutapa, jossa toiset kannattavat "järkevää" ja "reaalista" taloudenhoitoa, kun taas vastustajat pyrkivät kyseenalaistamaan talouden asiantuntijoiden aseman. Marja Keränen tuo esiin tätä puheen muutosta omassa artikkelissaan, jossa hän näyttää kuinka talouspuhe on yleistynyt poliittisessa puheessa kylmän sodan jälkeen ja kuinka se muokkautuu kansallisen kurinpidon keinoksi. Talouspuheen maailma on yksilöllistyvä, keske- nään kamppailevien yksilöiden maailma, jossa vain vahvimmat pärjäävät.

\section{Kirjan johtava ajatus on} ehkä ennen kaikkea vallitsevan taloustiedon ja -tieteen kritiikki nimenomaan naisten näkökulmasta. Vallitseva tietomme taloudesta mykistää usein naiset ja piilottaa heidän merkityksensä. Monet artikkelit pyrkivät tarkastelemaan nimenomaan taloudesta puhumisen tapoja ja katsomaan niiden taakse.

\section{Kirja nostaa aluksi esiin} naisten tekemän työn taloudessa konkreettisesti tilastojen valossa. Johanna Varjonen ja Anita Haataja osoittavat, kuinka suuri merkitys naisten tekemällä työllä on kansantalouden pyörittämisessä, vaikka se luvuista ei aina näkyisikään.

\section{Vuokko Jarva ja Hilkka}

Pietilä kehittelevät uudenlaisia tapoja käsitteellistää talous niin, että myös naisten antama panos ja sen merkitys nousisi esiin. He näkevät, että vallitseva talouskäsitys edustaa miehistä tapaa toimia ja nähdä asiat abstrahoidusti ja korostavat, että naisten näkökulma nousee arjesta ja ruohonjuuritasolta, "todellisesta" elämästä ja jää usein huomaamatta virallisilta talousmittareilta.

Kirja tarjoaa myös hyvän johdatuksen taloustieteen kriittisiin arvioihin. Taloustietoa käytetään, kuten MarjaLiisa Kakkuri-Knuuttila kirjoittaa, tuottamaan täsmällistä tietoa yhteiskunnalliseen päätöksentekoon. Tällöin usein unohtuu, että varman näköiset luvut sisältävät paljon epävarmuutta ja varauksia. Mittarit voivat kuvata todellisuutta vain vajavaisesti ja siksi ne eivät tee päätöksiä ihmisten puolesta. Ongelmat eivät ole näin niinkään oikean ja väärän tiedon kysymyksiä, vaan kysymyksiä tiedon laadusta ja sen esittämisen tavoista.

\section{Johanna Moisander}

pohtii samoja asioita analysoimalla suomalaista Emu-keskustelua ja pyrkii näyttämään taloustieteellisen tiedon rajoja. Kuten Moisander huomauttaa, keskustelua vaivaa usein jakautuminen taloustieteelliseen kapulakieleen ja toisaalta "pienen ihmisen" protestiin "talouden" kasvavaa valtaa vastaan. Taloustieteellä on taipumus erkaantua omaksi maailmakseen, joka hämärtää alleen poliittisten kysymysten erilaiset vaihtoehdot ja arvovalinnat. Leena Kerkelä pyrkii puolestaan purkamaan kansainvälisen kaupan teoriaa ja pohtii sitä, kuinka talouden kansainvälistyminen saattaa uhata suomalaista naisvaltaista julkista sektoria.

\section{Kokonaisuutena kirja} antaa erilaisia näkökulmia siihen, miten naisten ja talouden suhdetta voi käsitteellistää ja ymmärtää paremmin ja samalla se avautuu laajaksi pohdinnaksi talouden merkityksestä nyky-yhteiskunnassa. Talous sinällään ei tarkoita mitään, ja sen vuoksi on tärkeää pyrkiä purkamaan talou- 
den käsitettä ja ymmärtämään, mitä talouden nimissä pyritään tekemään ja millaista poliittista vallankäyttöä siihen liittyy. Kirja onkin parhaimmillaan haastaessaan avaamaan talouden tuottamia "totuuksia" ja arvovapaita lukuja.

\section{Artikkeleista löytyy}

kirjavuutta, mutta se ei välttämättä ole suuri ongelma. Kirjan toimittanut Tiina Vainio pohtii lopuksi itsensä Jacques Derridan innoittamana taloustieteen diskursiivisuutta. Hän kiinnittää huomion nimenomaan taloustieteen muotoon, erityisesti sen arvovapauteen. Vainio pohtii kielen tuottamien erottelujen ongelmallisuutta. Kieli luo väistämättä kategorioita ja samalla sulkee ulos todellisuuden osia ja ulottuvuuksia. Tässä mieles- sä myös naisten talouskirja sisältää paradoksin. On vaikea puhua myös naisten taloudesta, koska naiseutta on ongelmallista määritellä kovin tiukasti tai yksiselitteisesti.

\section{Naisten ja talouden}

teeman yhdistäminen ja naulaaminen kiinni yhdeksi näkökulmaksi voisi ollakin vielä ongelmallisempaa kuin nyt valittu erilaisten näkökulmien kirjo. Pahimmillaan syntyy stereotyyppinen jako, jossa miehet samastetaan taloudelliseen abstraktiin järkeen ja naiset puolestaan kotielämän ja arjen tunteisiin. Tähän kahtiajakoon kirja ei onneksi juuri lankeakaan.

\section{Ehkä onkin parempi} nähdä naisten ja talouden kohtaamispiste areenana, jossa erilaiset tarkastelun tasot ja näkökulmat kohtaavat ja voidaan ottaa pohdinnan alle. Voidaan puhua kotityön nostamisesta esiin, julkisten naisvaltaisten alojen kohtalosta, kehitysmaiden naisten tekemästä työstä, tilastojen tietoopista tai järjen määrittelemisestä, mutta lopullista ja tyhjentävää totuutta naisista ja taloudesta on parasta olla sanomatta. Kirja täyttää tehtävänsä tässä mielessä hyvin. Se pistää miettimään talouslukujen syntyä ja käyttöä, ja antaa pohdintaan sekä konkreettisia että abstraktimmalle tasolle nousevia filosofisempia ajatuksia.

Anu Kantola 